\title{
Ibm Masyarakat Duasudara Kecamatan Ranowulu Bitung Dalam Melestarikan Kupu-Kupu Dilindungi, Endemik dan Terancam Punah
}

\author{
Hanny Hesky Pontororing ${ }^{1}$, Hanri Jefry Lengkong ${ }^{1}$ \\ ${ }^{1}$ Program Studi Biologi Fakultas Matematika dan Ilmu Pengetahuan Alam \\ Universitas Sam Ratulangi Manado, 95115, Sulawesi Utara, Indonesia. \\ *Penulis Korespondensi. Email: hannypontororing@unsrat.ac.id
}

\begin{abstract}
ABSTRAK
Kekayaan hayati di CA DuaSudara sangat tinggi, bahkan beberapa di antaranya bersifat endemik atau distribusinya terbatas di sebagian Kawasan Sulawesi saja. Beberapa contohnya adalah Monyet Hitam Sulawesi (Macaca nigra), Tangkasi (Tarsius spectrum), dan Burung Rangkong (Rhyticeros cassidix), Selain satwa khas Sulawesi yang telah banyak dikenal, terdapat juga kupu-kupu yang endemik Sulawesi seperti spesies Troides yang di Sulawesi terdapat dua supspesies yaitu supspesies Troides helena celularis dan Troides hipolitus. Salah satu kelemahan Masyarakat Kelurahan Duasudara adalah kurang menguasai tentang pengetahuan konservasi, manfaat kupu-kupu serta teknik identifikasi flora dan fauna, serta metode konservasi dilapangan. Kegiatan Ibtek bagi Masyarakat ini dilaksanakan di Kelurahan Dua Sudara Keamatan Ranowulu Bitung Sulawesi Utara. Metode yang digunakan dalam Kegiatan PKM ini metode ceramah dan diskusi. Peserta kegiatan ini adalak Lurah Kelurahan Dua Sudara, Aparat Kelurahan, Tokoh Masyarakat dan Karang Taruna Kelurahan Dua Sudara. Bedasarkan hasil kegiatan yang telah dilakukan terhadap Masyarakat Kelurahan Dua Sudara, dapat meningkatkan pemahaman masyarakat tentang keberadaan Spesies Troides yang merupakan kupu-kupu yang dilindungi dan terancam punah.
\end{abstract}

Kata kunci: Spesies Troides, DuaSudara

\section{ABSTRACT}

Biodiversity in the DuaSudara Nature Reserve is very high, some of which are even endemic or their distribution is limited in parts of Sulawesi. Some examples are the Sulawesi black monkey (Macaca nigra), tangkasi (Tarsius spectrum), and hornbills (Rhyticeros cassidix). There are also butterflies endemic to Sulawesi, such as the Troides species which in Sulawesi have two supspecies, namely the supspecies Troides helena celularis and Troides hypolitus. One of the weaknesses of the Duasudara Village Community is that they lack knowledge of conservation knowledge, the benefits of butterflies as well as flora and fauna identification techniques, as well as field conservation methods. This Community Service Activity is carried out in Duasudara Village, Ranowulu Bitung District, North Sulawesi. The method used in this PKM activity is lecture and discussion methods. Participants in this activity are the Head of the Dua Sudara Urban Village, Village officials, community leaders and youth groups of Dua Sudara Village. Distinguishing the results of activities that have been carried out with the Dua Sudara Village Community, can increase community understanding of the existence of the Troides species, which is a protected and endangered butterfly

Keywords: Troides Species, DuaSudara 
kupu sehingga kelurahan ini berpotensi untuk dijadikan kelurahan konservasi kupukupu di Bitung Sulawesi Utara. Untuk itu perlu dilakukan peningkatkan pendidikan bagi masyarakat Kelurahan Duasudara.Yang menjadi inti PKM ini yaitu meningkatkan pendidikan secara informal bagi masyarakat kelurahan Duasudara yaitu pengenalan tentang kupu-kupu dan konservasinya serta potensi kelurahan Duasudara untuk dijadikan Kelurahan konservasi kupu-kupu yang dapat dikembangkan menjadi Kelurahan Wisata Kupu-kupu di Sulawesi Utara.

Oleh karena itu perlu dilakukan berbagai upaya peningkatan pendidikan dan penyadaran di kalangan masyarakat Kelurahan Duasudara, maka perlu dilaksanakan peningkatan pemahaman tentang kupu-kupu dan pelatihan pelestarian lingkungan hidup bagi masyarakat Kelurahan Duasudar dan untuk meningkatkan pengetahuan dan keterampilan dalam berbagai upaya nyata untuk berperan aktif dalam mengelola lingkungan hidup

Kegiatan PKM bagi masyarakat kelurahan Duasudara sesuai dengan renstra perguruan tinggi yaitu melaksanakan penelitian dibidang satwa lokal dan dilaksanakan untuk kesejahtraan bagi masyarakat Sulawesi utara sehingga sejalan dengan tujuan renstra Universitas Sam Ratulangi.

\section{Permasalahan Mitra}

Salah satu kelemahan Masyarakat Kelurahan Duasudara adalah kurang menguasai tentang pengetahuan konservasi, manfaat kupu-kupu serta teknik identifikasi flora dan fauna, serta metode konservasi dilapangan. Hal ini disebabkan karena beberapa faktor, antara lain:

1. Pendidikan mitra yang sangat bervariasi, dari tidak sekolah sampai dengan tingkat sarjana. 
2. Latar belakang pendidikan yang tidak terkait dengan aktivitas konservasi serta pemahaman tentang wisata alam.

3. Kurangnya pelatihan di bidang konservasi, identifikasi flora fauna, dan metode konservasi dilapangan serta pemahaman tentang perilaku kupu-kupu dilapangan

Oleh karena itu, peran para pemerintah sebagai pengambil kebijakan dan masyarakat sebagai pemanfaatan kebijakan tentang manfaat dan peningkatan ketrampilan tentang sangat terbatas sehingga dapat dijadikan sebagai tempat Wisata. Hasil konservasi dapat meningkatkan penghasilan bagi masyarakat dengan dijadikan kelurahan kawasan konservasi maka dapat menjadi pemasukan devisa bagi pemerintah dan masyarakat kelurahan Duasudara. Dengan pengetahuan dan keterampilan tambahan seperti misalnya dalam watching atau identifikasi kupu-kupu, bahkan sebagai enumerator peneliti, maka masyarakat akan mendapatkan tambahan pendapatan.

Dengan demikian hasil kesepakatan antara pengusul dan mitra skala priotitas paling tinggi dalam kegiatan PKM ini adalah pelatihan tentang konservasi kupu-kupu identifikasi, dan metode konservasi exsitu dan eksitu sehingga masyarakat Kelurahan Duasudara memahami tentang Kelurahan Duasudara yang dapat dikembangkan menjadi Kelurahan KOnservasi Kupu-kupu yang dapat dikembangkan menjadi Kelurahan Wisata Kupu-kupu di Sulawesi Utara.

\section{METODE PELAKSANAAN}

\section{Sasaran Kegiatan Pengabdian}

Mitra kegiatan ini adalah masyarakat Kelurahan Dua Sudara yang terdiri atas Aparat Pemerintah dan Tokoh Masyarakat
Seta Pemuda dan Renaja Kelurahan DuaSudara Bitung.

\section{Lokasi Kegiatan Pengabdian}

Kegiatan Pengabdian di Kelurahan Dua Sudara Dilaksanakan di Gedung Tiga Pilar Kelurahan Dua Sudara.

\section{Metode yang digunakan}

Metode yang digunakan dalam Kegiatan PKM ini metode ceramah dan diskusi dengan materi:

- Pengenalan tentang kupu-kupu

- Kupu-kupu endemik dan terancam punah

- Metode inventarisasi kupu-kupu

- Pengenalan Tanaman inang

- Metode Penemuan tanaman inang

- Perbanyakan tanaman inang (Dewasa dan Pradewasa

- Pengertian konservasi

- Undang-Undang dan peraturan tentang konservasi

- Macam-macam kawasan konservasi

- Status konservasi flora fauna menurut Peraturan Pemerintah serta IUCN.

- Potensi Kelurahan Duasudara untuk dijadikan kelurahan Konservasi/ wisata kupu-kupu di Sulawesi Utara.

Kontribusi masyarakat dalam kegiatan PKM adalah berpartisipasi langsung dengan menghadiri setiap kegiatan yang dilakukan seperti menghadiri kegiatan ceramah dan diskusi, berpartisipasi aktif dalam kegiatan ceramah dan diskusi, mnengikuti kegiatan praktek lapangan yang dilaksanakan untuk menambah ketrampilan dalama bidang konservasi kupu-kupu serta berperan aktif dalam pembentukan kawasan konservasi eksitu dan in-situ serta ikut serta ikuit serta dalam mengembangkan potensi kelurahan duasudara menjadi kelurahan koservasi kupu-kupu di Sulawesi Utara. 


\section{HASIL DAN PEMBAHASAN}

Iptek bagi Masyarakat Kelurahan Dua Sudara Kecamatan Ranowulu Bitung dalam melestarikan kupu-kupu yang dilindungi dan teracam punah telah dilaksanakan pada tanggal 29 Oktober 2020 dan dihadiri oleh Lurah Dua Sudara beserta staf dan para Aparat kelurahan serta pimpinan organisasi masyarakat serta pimpinan dan anggota karang taruna kelurahan Dua Sudara. Kegiatan IbM di Kelurahan Dua Sudara dilaksanakan di Gedung Tiga Pilar Kelurahan Dua Sudara. Kegiatan diawali dengan Doa Oleh salah seorang peserta IbM dan Dilanjutkan dengan Sambutan Lurah Dua Sudara (Gambar 1), dalam Sambutannya Lurah Dua Sudara mengapresiasi kegiatan IbM yang dilakukan Oleh Tim IbM dari Unsrat.

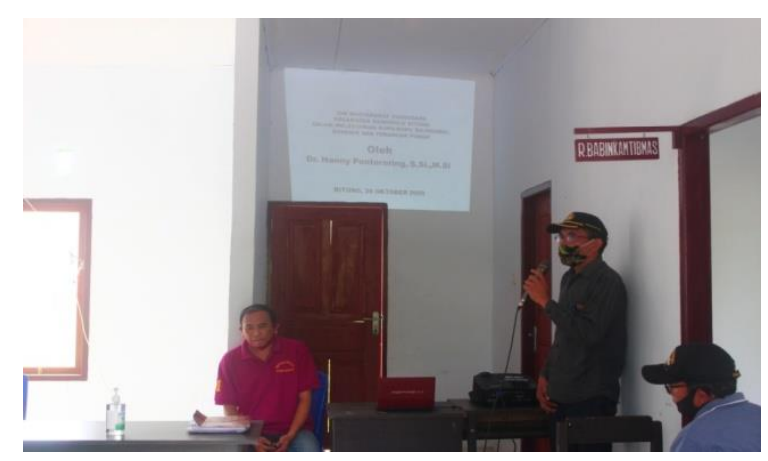

Gambar 1. Sambutan Lurah Kelurahan Dua Sudara, Bitung

Kegiatan IbM dilaksanakan dalam bentuk:

a. Diskusi awal tentang pengetahuan dasar tentang kupu-kupu bagi peserta dan pada umumnya semua peserta mengetahui tentang kupukupu sebab dikelurahan Dua Sudara terdapat beberapa jenis kupu-kyupu yang sering terbang di seputar pekarangan masyarakat, namun mereka tidak mengetahui manfaat dan keberadaan kupu-kupu tersebut, bahkan ada yang memahami bahwa kupu-kupu itu apabila dalam keadaan perkembangannya (dalam bentuk ulat, itu berada dalam keadaan yang sangat menjijikkan bahkan dapat mengakibatkan keracunan apabila tersentuh oleh manusia. Bahkan keberadaan kupu-kupu yang dewasa itu hanya sebagai permainan anakanak bahkan tidak ada seorangpun yang memperhatikan tentang keberadaan kupu-kupu disekitarnya.

b. Penyampaian materi dilakukan dengan pemaparan materi dalam bentuk slait pawerpoin (Gambar 2).

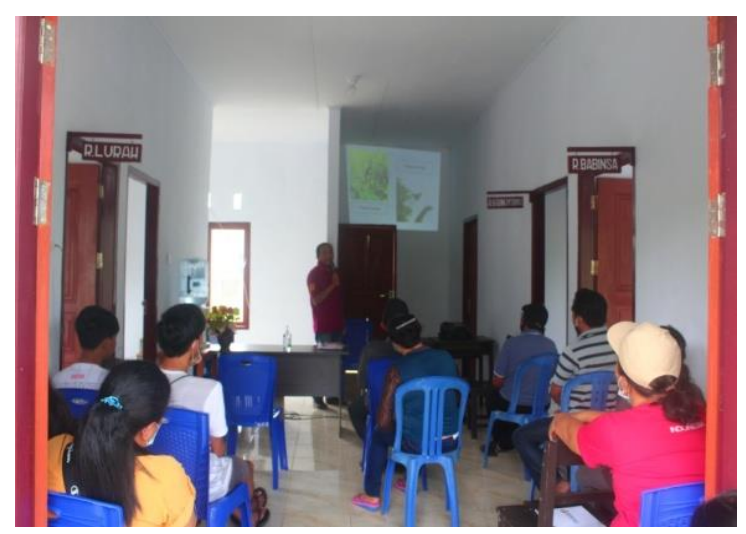

Gambar 2. Pemberian Materi

Materi yang diberikan menjelaskan tentang keberadaan kupu-kupu secara peraturan UUN RI, dijelaskan bahwa terdapat beberapa kupu-kupu yang dilindungi oleh undang-undang. Dalam penyampaian materi dijelaskan bahwa di kelurahan Dua Sudara terdapat 2 jenis kupukupu yang dilindungi oleh pemerintah yaitu kupu-kupu jenis Troides. Dijelaskan juga bahwa si daerah sekitar kelurahan dua sudara terdapat dua jenis triodes dari 4 jenis yang ada di Sulawesi yaitu 1 endemik Sulawesi Selatan, dua berada di Kelurahan dua Sudara dan satu jenis terdapat di Kepulawan Sangihe dan Talaud dan bersifat endemik. Secara umum dijelaskan bahwa kelurahan Dua Sudara patut bersyukur bahwa disekitar kawasan Dua Sudara terdapat dua jenis kupu-kupu yang dilindungi dan reancam punah terdapat di sekitar kelurahan Dua Sudara, Ini ditunjang keberadaan kelurahan Dua Sudara yang di 
3. Peningkatan pemanfaatan tentang manfaat dan kegunaan kupu-kupu di alam.

\section{Saran}

Perlu dilakukan kegiatan pengabdian untuk menjadikan daerah kelurahan Duasudara dijadikan sebagai daerah wisata kupu-kupu di Sulawesi Utara.

\section{UCAPAN TERIMA KASIH}

Terima kasih banyak kepada Lembaga Penelitian dan Pengabdian Universitas Sam Ratulangi yang telah membiayai kegiatan ini. Terima kasih juga kepada mitra kegiatan ini yaitu Lurah, Aparat Pemerintah dan tokoh masyarakat serta pemuda dan remaja kelurahan Dua Sudara yang telah berperan aktif pada kegiatan ini.

\section{DAFTAR PUSTAKA}

Achmad. A. 2002. Potensi dan Sebaran Kupu-kupu di Kawasan Taman Wisata Alam Bantimurung. WorkshopPengelolaan Kupu-kupu BerbasisMasyarakat.Bantimurun. Diakses 31 Januari 2016.

keberadaanya dan dengan adanya pertemuan ini maka disaran kepada tim IbM utk dapat dikembangkan kelurahan Dua Sudara untuk dijadikan Kawasan Wisata Kupu-kupu di Sulawesi Utara.

\section{KESIMPULAN DAN SARAN}

\section{Kesimpulan}

Berdasarkan kegiatan yang dilakukan dapat disimpulkan:

1. Terjadi Peningkatan pemahaman tentang kupu-kupu yang dilindungi dan terancam punah

2. Peningkatan pemahaman tentang perilaku kupu-kupu
Bodang. Y. 2008. Beberapa aspek biologi kupu-kupu Troides helena hephaestus Felder (Papilionidae) pada tumbuhan Aristolochia tagala Cham. Agrotek 1 (3):20-25.

Departemen Kehutanan. 1990. Undangundang Republik Indonesia Nomor 5 Tahun 1990 tentang Konservasi Sumberdaya Alam Hayati dan Ekosistemnya. Jakarta.

Departemen Kehutanan. 1999 ${ }^{\mathrm{a}}$. Undangundang Republik Indonesia No 41 
Ecologi (Online). 15:2549-2563

Tahun 1999 tentang Kehutanan. Jakarta.

Hadi, M., U. Tarwanto dan R. Rahadian. 2009. Biologi Insekta (Entomologi). Graha Ilmu. Yogyakarta.

Hamidun, M.S.2001. Studi Kegiatan Konservasi Kupu-kupu di

Kecamatan Bantimurung Kabupaten Maros Sulawesi

Selatan.(Tesis).Program

Pascasarjana Universitas Hasanudin Makasar.

Indrawan, M., R.B. Primack \&J. Supriatna. 2007. Biologi Konservasi. Yayasan Obor Indonesia, Consevation International-Indonesia, Pusat Informasi Lingkungan Indonesia (PILI), Yayasan WWF Indonesia, Uni Eropa, YABSHI, Jakarta.

Hamidun, M.S. 2001. Studi Kegiatan Konservasi Kupu-kupu di kecamatan Bantimurung Kabupaten Maros Sulawesi selatan.Program Pascasarjana Unversitas Hasanudin Makasar.

Karangan, E. 1996.Studi Kelangsungan Hidup Kupu-kupu Troides hypolituscellularis Rothschild di Gua Pattunuang Kabubaten Maros Propinsi Sulawesi Selatan.Universitas Hasanudin Makasar.

Kinnaird, F.M. 1997. Sulawesi Utara. Sebuah Panduan Sejarah Alam. Jakarta: Percetakan Redikencana.

Nishida R, and H. Fukami. 1989. Ecological Adaptation of an Aristolochiaceaefeeding Swallowtail Butterfly Atrophaneura Alcinous to Aristolochic Acid. Journal Chemical (diakses 21 Februari 2016.

Nurjannah ST. 2010. Biologi Troides helena helena dan Troides helena hepaestus (Papilionidae) di penangkaran. Online

athttp://iirc.ipb.ac.id/jspui/bitstream, $p d f$. (diakses 8 Februari 2016)

Peggie, Dj. 2014. Mengenal Kupu-kupu. Pandu Aksara Publishing.Jakarta Indonesia.

Peggie, Dj. 2011.Precius and Protected Indonesian Butterflies (Kupu-kupu Indonesia yang Bernilai dan Dilindungi.PT Binamitra Megawarna, Jakarta, Indonesia.

Peggie.Dj. dan M. Amir. 2006 . Practical Guide to the Butterflies of Bogor Botanic Garden.Panduan Praktis Kupu-kupu di Kebun Raya Bogor. Pusat PenelitianBiologi, LIPI, Cibinong. Indonesia and Nagao Natural Environmental Foundation, Japan.

Tsukada, E. 1990.Butterflies of South East Asia Islands. Journal of Lepidopterist Society (Online) 44(2):107-110. Diakses 21 Februari 2016.

Tsukada, E. \& Y. Nishiyama. 1982. Butterfles of the South East Asia Island. Vol 1: Papilionidae. Plapac.Co.Ltd.Tokyo.

Vane-Wright, R.I \&R. D. Jong. 2003. The Butterflies of Sulawesi: annotated Checklist for a Critical Island Fauna. Zool.Vern. Leiden.fig 1-14, pls 1-16ISSN 0024-1652/ IsBN 90-7323987-7 